\title{
Metody i formy kształcenia w zakresie innowacyjnej przedsiębiorczości
}

DOI: 10.47050/65591760.234-250

Agnieszka Skala

Kształcenie w zakresie innowacyjnej przedsiębiorczości powinno się różnić od typowego programu nauczania przedsiębiorczości sensu largo. Specyfika przedsięwzięć innowacyjnych wymaga sięgnięcia po szczególne metody i formy kształcenia. W pierwszej części opracowania omówiono specyfikę fenomenu innowacyjnej przedsiębiorczości i obecne problemy edukacji dla przedsiębiorczości dyskutowane w literaturze przedmiotu. W drugiej części przedstawiono propozycję struktury zajęć opartych na pracy projektowej, uwzględniając treści poszczególnych modułów związanych z przekazywaniem wiedzy, rozwijaniem i ćwiczeniem umiejętności oraz kształtowaniem odpowiednich postaw wśród słuchaczy.

\section{Słowa kluczowe:}

edukacja dla przedsiębiorczości

przedsiębiorczość innowacyjna

kształcenie projektowe

struktura zajęć 


\section{Education for Innovative Entrepreneurship - Methods and Forms Applied}

DOI: $10.47050 / 65591760.234-250$

Agnieszka Skala

New methods and forms of education are applied when it comes to innovative entrepreneurship, instead of "typical" training curriculum. The first part of the text discusses the specificity of the innovative entrepreneurship as an economic phenomenon and the current problems of education for entrepreneurship discussed in the literature. The second part presents a proposal for a project-based curriculum structure, taking into account the content of modules related to transferring knowledge, developing and practicing skills, and shaping appropriate attitudes among the students.

\section{- Keywords: \\ entrepreneurship education \\ innovative entrepreneurship \\ project-based learning \\ curriculum structure}




\section{Innowacyjna przedsiębiorczość}

Powiązanie przedsiębiorczości z innowacyjnością wprowadził do nauk ekonomicznych Joseph Schumpeter (1942), przekonując, że zagrożenie radykalnie lepszymi rozwiązaniami zmusza głównych graczy rynkowych ${ }^{1}$ do ponoszenia nakładów na prace badawczo-rozwojowe, których wdrożenia skutkują rozwojem gospodarczym i cywilizacyjnym. Podobnie Peter Drucker (1992) uważał, że tylko przedsiębiorcy tworzący nowe rynki lub wdrażający nowe rozwiązania reprezentują "prawdziwą" przedsiębiorczość, bez względu na poziom zainwestowanych środków czy wielkość tworzonego przez nich zatrudnienia. W opozycji do tego poglądu wypowiadał się William Baumol (2010) - doceniał imitatorów, którzy dzięki drobnym usprawnieniom (tak zwanym innowacjom inkrementalnym) nierzadko osiągają w dłuższej perspektywie czasowej lepsze wyniki biznesowe niż pionierzy i innowatorzy. Polemika na temat znaczenia innowacji i imitacji pozostaje jednym z nierozstrzygniętych sporów w obszarze badań nad przedsiębiorczością. Jerzy Cieślik (2014) proponuje podejście realne (bliższe Williamowi Baumolowi), uznające imitacje i niewygórowane ambicje przedsiębiorcze za ważne z punktu widzenia rozwoju przedsiębiorczości i całej gospodarki. Podobne stanowisko można znaleźć w pracy Joerna $\mathrm{H}$. Blocka, Christiana O. Fischa i Mirjam van Praag (2017), którzy za innowatorów, poza wynalazcami i naukowcami, uważają także przedsiębiorców lub pracowników, którzy tworzą i wdrażają innowacje raczej umiarkowane.

Nieco inaczej sprawa ta wygląda z punktu widzenia makroekonomii. Odkąd wyniki badań Davida Bircha $(1979,1987)$ wykazały, że to małe firmy (a nie korporacje) tworzą większość nowych miejsc pracy w Stanach Zjednoczonych² , zintensyfikowano badania nad wpływem przedsiębiorczości i samozatrudnienia na szeroko rozumiany rozwój gospodarczy i poziom dobrobytu. Wnioski po niemal trzech dekadach badań wciąż nie są w pełni jednoznaczne (Block, Fisch, van Praag 2017). Nie ulega wątpliwości, że większość osób zaangażowanych w tworzenie nowych przedsiębiorstw prowadzi działalność wyłącznie "na własne potrzeby" (subsistence), w ogóle nie zatrudnia pracowników,

1. Używa się także określenia "firmy zasiedziałe” (incumbents).

2. Wnioski te również zostały później podważone - miejsca pracy tworzą głównie firmy młode, a nie małe (Haltiwanger, Jarmin, Miranda 2013), jeszcze innym problemem pozostaje jakość tych etatów (Coad i in. 2014). 
wykazuje minimalne dochody (Shane 2008) i nie przejawia ambicji rozwojowych (Ng, Stuart 2016, Schoar 2010). Nie zmienia to faktu, że wpływ tworzenia nowych firm na liczbę miejsc pracy w krajach OECD jest pozytywny (Calvino, Criscuolo, Menon 2016, Criscuolo, Gal, Menon 2014). Równocześnie inne badania dowiodły, że tylko niewielka liczba udanych wdrożeń przełomowych innowacji, wprowadzanych na rynek zarówno przez firmy zasiedziałe, jak i szybko rosnące start-upy, jest odpowiedzialna za nadproporcjonalne zwiększenie liczby miejsc pracy i wzrost wydajności (Andrews, Criscuolo, Menon 2014). Inaczej mówiąc - mała część przedsiębiorstw odgrywa naprawdę przełomową, napędzającą rolę w gospodarce (por. Cieślik 2018). Są to przedsięwzięcia wdrażające innowacje (nie tylko produktowe), cechuje je ambitna wizja i wysoka dynamika rozwoju, przez to są również ekspansywne i nastawione na rynki globalne. Często występuje w nich komponent technologiczny, nierzadko związany z obszarem ICT ${ }^{3}$. Ich udział w ogólnej liczbie przedsiębiorstw szacuje się na 2-6 proc. (OECD 2015, Wong, Ho, Autio 2005).

Co ciekawe, obserwuje się obecnie tendencję spadkową w zakresie całkowitej liczby rejestracji nowych firm (Blanchenay i in. 2017; Decker i in. 2016), jednocześnie jednak rośnie odsetek przedsięwzięć finansowanych przez fundusze venture capital (VC), podobnie jak wielkość tych inwestycji, które w 2015 r. były o 50 proc. wyższe niż w 2007 r. (w krajach OECD). W Stanach Zjednoczonych odnotowano analogiczną tendencję, a także rosnącą liczbę "jednorożców" (unicorns), czyli innowacyjnych firm branży ICT wycenianych na co najmniej $1 \mathrm{mld}$ dol. amerykańskich (Guzman, Stern 2016).

W tym ujęciu priorytety polityki państw propagujących przedsiębiorczość ulegają przeformułowaniu (Rannikko, Autio 2016, Kösters 2010), co obserwujemy również w Polsce (Stępniak-Kucharska 2015). Celem przestaje być propagowanie przedsiębiorczości jako takiej - zwłaszcza w wymiarze zwiększenia liczby nowych rejestracji - lecz wypracowanie precyzyjnych instrumentów wsparcia dla innowacyjnej, prorozwojowej i dynamicznej przedsiębiorczości. Najciekawsze studia przypadku pokazują, że realne efekty pojawiają się poza głównym nurtem „polityki przedsiębiorczości" i występują w takich obszarach jak ubezpieczenia 
społeczne i zdrowotne (Fairlie, Kapur, Gates 2011), a przede wszystkim - edukacja.

\section{Kształcenie dla innowacyjnej przedsiębiorczości}

Edukacja w zakresie przedsiębiorczości jest uznanym kierunkiem badań naukowych (Kuratko 2005, Vesper, Gartner 1997) oraz kluczowym elementem budowania przedsiębiorczej kultury i gospodarki (McKeown i in. 2006, Matley 2005, Kirby 2004, McMullan, Long 1987), także w Polsce (Sadowska 2016, Wach 2013). Większość uczonych twierdzi zgodnie, że nauczenie się przedsiębiorczości jest możliwe (Fayolle, Lassas-Clerc 2006, Henry i in. 2005a, 2005b), a badania Alberty Charney i Gary'ego Libecapa (2000) dowiodły, że studenci wykształceni w kierunku przedsiębiorczości są nie tylko bardziej skłonni do zakładania własnych firm (co jest raczej oczywistym wnioskiem), ale także wyraźnie częściej niż inni znajdują zatrudnienie w firmach szybko się rozwijających (high-growing) lub realizują ważne projekty związane z rozwojem nowych produktów w ramach dużych organizacji.

W literaturze na temat kształcenia na rzecz przedsiębiorczości dominują prace dotyczące struktury i curriculum zajęć oraz konkretnych technik i metodyk nauczania. Brakuje opracowań przeglądowych i strategicznych, wytyczających najważniejsze kierunki badań oraz omawiających ich zastosowanie. Wiedzę o kształceniu na rzecz przedsiębiorczości można określić jako rozproszoną, a o niedojrzałości tej subdyscypliny świadczą wciąż nierozstrzygnięte spory i dyskusje o definicjach i stosowanej nomenklaturze (Mwasalwiba 2010). Choć nie podlega już dyskusji, że edukacja dla przedsiębiorczości wywiera potężny wpływ na biznes, to nie został jeszcze wypracowany zadowalający warsztat metodyczny, pozwalający na przeprowadzenie badań nad efektywnością zastosowania różnych narzędzi edukacyjnych (por. Skala 2016, Pittway, Cope 2007). Na marginesie tych rozważań warto dodać, że specjalizacja w zakresie edukacji nie jest postrzegana jako kierunek badawczy gwarantujący szybką karierę akademicką, w każdym razie istnieją inne specjalizacje w obszarze przedsiębiorczości, które są odbierane jako bardziej atrakcyjne pod tym względem (Kuckertz, Prochotta 2018, Kuckertz 2013). Grozi to negatywnym wyborem tej specjalności przez młodych naukowców.

W wymiarze kształcenia na rzecz przedsiębiorczości innowacyjnej wśród trzech głównych składowych edukacji przedsiębiorczości 
- ekonomicznej, biznesowej (zarządczej) i indywidualnej (por. Wach 2013) - coraz większego znaczenia nabiera ostatnia z wymienionych. Chodzi tutaj głównie o pobudzanie efektuacyjnego sposobu myślenia i działania (Kurczewska 2012), krzewienie otwartej i kolaboracyjnej kultury biznesu oraz wskazywanie korzyści z aktywnego uczestnictwa w społecznościach biznesowych (Skala 2018). Wobec deficytu tych tematów w ramach edukacji formalnej coraz częściej źródłem wiedzy dla przedsiębiorców jest edukacja nieformalna. Andrzej Koźmiński (2011) zauważył, że przedsiębiorczość jest w polskich szkołach utożsamiana przeważnie z drobną wytwórczością (na przykład rzemiosłem) i rodzinnym, nieskomplikowanym biznesem, co eliminuje z programów nauczania elementy myślenia kreatywnego i nieszablonowego (out of the box thinking). Tymczasem to, czego należy nauczać, to twórcza przedsiębiorczość intelektualna i wewnętrzna przedsiębiorczość korporacyjna (intrapreneurship). Plany z tym związane są na szczęście widoczne w treściach nauczania w nowej podstawie programowej kształcenia ogólnego dla liceum ogólnokształcącego i technikum, w których jest mowa o start-upach i innowacyjnych modelach biznesowych ${ }^{4}$.

\section{Metody i formy kształcenia}

Przywoływany wcześniej Andreas Kuckertz (2013) akcentuje dwa elementy, które powinny znajdować się w programach nauczania innowacyjnej przedsiębiorczości: dostarczanie wzorców przedsiębiorców, z którymi adepci mogą się identyfikować (case studies lub spotkania z przedsiębiorcami) oraz nauczanie metodą projektową (project based learning, learning by doing) lub odbywanie staży w start-upach. Podobnie Krzysztof Wach (2013) zwraca uwagę, że program nauczania przedsiębiorczości powinien zawierać takie elementy, jak rozwijanie cech i umiejętności przedsiębiorczych oraz realizowanie projektów biznesowych. Jeff Vanevenhoven (2013), idzie jeszcze dalej i postuluje „wyjście nauczycieli zza biurek, a uczniów z klas". Poza przekazaniem podstawowej wiedzy kształcenie na rzecz innowacyjnej przedsiębiorczości powinno kształtować komplementarne dla wiedzy umiejętności, w tym zwłaszcza efektywną pracę zespołową.

4. Rozporządzenie Ministra Edukacji Narodowej z dnia 30 stycznia 2018 r. w sprawie podstawy programowej kształcenia ogólnego dla liceum ogólnokształcącego, technikum oraz branżowej szkoły II stopnia (Dz.U. 2018, poz. 467). 
Szczupłe ramy niniejszego opracowania nie pozwalają na szerokie omówienie wielu metod i form kształcenia w zakresie innowacyjnej przedsiębiorczości. Dlatego uwaga zostanie skoncentrowana na trzech najważniejszych zagadnieniach w tym zakresie:

$\rightarrow$ formie zajęć,

$\rightarrow$ kompetencjach prowadzącego,

$\rightarrow$ osadzeniu zajęć w ekosystemie przedsiębiorczości.

\section{Forma zajęć}

W wypadku innowacyjnej przedsiębiorczości dobrze się sprawdza zbudowanie procesu kształcenia wokół pracy projektowej w grupach (najlepiej dwu- lub trzyosobowych). W uproszczeniu proces ten składa się z trzech głównych elementów (Rys. 1):

$\rightarrow$ opracowania idei projektu w formule: "Kto jest klientem (użytkownikiem)?", "Jaki ma problem?", "Jakie proponujemy rozwiązanie?",

$\rightarrow$ weryfikacji projektu przy użyciu odpowiedniego zestawu narzędzi, głównie modelowania biznesowego,

$\rightarrow$ prezentacji końcowej projektu.

Rysunek 1. Główne etapy rozwoju projektu przedsiębiorczości innowacyjnej w procesie kształcenia

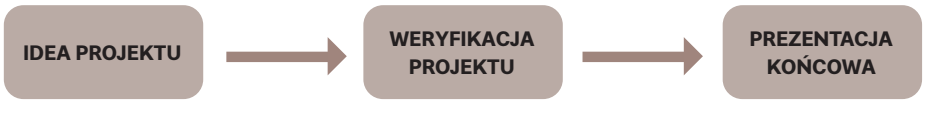

Źródło: Opracowanie własne.

Każdy element tej triady jest równie ważny. Często popełniany błąd (zarówno przez studentów, jak i przez prowadzących) polega na nadmiernym przywiązywaniu wagi do samego pomysłu na projekt jako elementu decydującego o całym jego potencjale i o ocenie pracy studentów podczas semestru. Pomysł na projekt powinien również spełniać pewne warunki, aby móc być uznany za innowacyjny: musi zawierać w sobie element nowości i nie może powielać pospolitych lub typowych modeli biznesowych (na przykład tanio kupił - drożej sprzedał), być franszyzą lub przedstawicielstwem innej firmy. 
Na każdym etapie kształcenia realizowanego w formule projektowej można wyróżnić elementy: przekazywania wiedzy, doskonalenia umiejętności i kształtowania postaw proprzedsiębiorczych (Tab. 1). Na etapie formułowania idei projektu (ok. 20 proc. czasu przeznaczonego na zajęcia - w trakcie zarówno spotkań, jak i pracy samodzielnej studenta) w ramach form wykładowych należy pomóc studentom odnaleźć interesującą ich tematykę projektu: omówić case studies, wskazać bazy danych, w których mogą znaleźć inspirację, dowiedzieć się, co w interesujących ich obszarach rozwijają realni przedsiębiorcy (na przykład baza Crunchbase, strona internetowa angel.co, baza na stronie fundacji Startup Poland). Warto sięgnąć po aktualizowane co pół roku opracowanie najciekawszych obszarów powstawania nowych rozwiązań biznesowych, przygotowane przez YCombinator, jeden z najlepszych akceleratorów młodych biznesów z Doliny Krzemowej (www.ycombinator.com/rfs). Warsztaty na tym etapie pracy polegają głównie na omawianiu i dopracowywaniu pomysłów, z elementami twórczego rozwiązywania problemów (design thinking) i ćwiczenia myślenia efektuacyjnego (por. Sarasvathy 2008). Rezultatem pracy jest koncepcja projektów w formule: klient - problem - rozwiązanie oraz uformowanie zespołów projektowych. 
Tabela 1. Metody i formy kształcenia na różnych etapach rozwoju projektu przedsiębiorczości innowacyjnej

\begin{tabular}{|c|c|c|c|}
\hline $\begin{array}{l}\text { ETAP PROJEKTU } \\
\text { / FORMA } \\
\text { KSZTAKCENIA }\end{array}$ & IDEA PROJEKTU & WERYFIKACJA PROJEKTU & $\begin{array}{l}\text { PREZENTACJA } \\
\text { KOŃCOWA }\end{array}$ \\
\hline $\begin{array}{l}\text { WYKŁADY } \\
\text { (WIEDZA) }\end{array}$ & $\begin{array}{l}\text { inspiracje, case } \\
\text { studies, inwentyka, } \\
\text { efektuacja }\end{array}$ & $\begin{array}{l}\text { modelowanie biznesowe, odkrywa- } \\
\text { nie klienta } \rightarrow \text { wywiady, analiza ryn- } \\
\text { ku i konkurencji, analiza zasobów, } \\
\text { strategie marketingowe, idea MVP, } \\
\text { monetyzacja }\end{array}$ & $\begin{array}{l}\text { formuła DemoDay, } \\
\text { sztuka prezentacji, } \\
\text { struktura i forma } \\
\text { prezentacji }\end{array}$ \\
\hline $\begin{array}{c}\text { WARSZTATY } \\
\text { (UMIEJĘTNOŚCI) }\end{array}$ & $\begin{array}{l}\text { design thinking, } \\
\text { budowanie zespo- } \\
\text { łu (team building) }\end{array}$ & $\begin{array}{l}\text { modelowanie biznesowe } \rightarrow \\
\text { stawianie hipotez, projektowanie } \\
\text { wywiadów, budowanie strategii } \\
\text { marketingowej, budowanie modeli } \\
\text { przychodowych, planowanie i reali- } \\
\text { zacja działań }\end{array}$ & $\begin{array}{l}\text { struktura i forma } \\
\text { prezentacji - przy- } \\
\text { gotowanie i próby }\end{array}$ \\
\hline $\begin{array}{c}\text { PRACA } \\
\text { PROJEKTOWA } \\
\text { (UMIEJĘTNOŚCI) }\end{array}$ & $\begin{array}{l}\text { pomysły projek- } \\
\text { towe w konwencji: } \\
\text { klient } \rightarrow \text { problem } \rightarrow \\
\text { rozwiązanie }\end{array}$ & $\begin{array}{l}\text { budowanie modeli biznesowych } \\
\text { i ich weryfikacja, przeprowadzenie } \\
\text { wywiadów, prototypowanie (MVP) }\end{array}$ & $\begin{array}{l}\text { przygotowanie } \\
\text { prezentacji }\end{array}$ \\
\hline $\begin{array}{l}\text { WEJŚCIE } \\
\text { W EKOSYSTEM } \\
\text { PRZEDSIĘBIOR- } \\
\text { CZOŚCI (POSTAWY } \\
\text { PROPRZEDSIĘ- }\end{array}$ & \multicolumn{2}{|l|}{ mentoring } & $\begin{array}{l}\text { publiczność na } \\
\text { DemoDay: przed- } \\
\text { siębiorcy, inwe- } \\
\text { storzy, członkowie } \\
\text { społeczności }\end{array}$ \\
\hline KCZLE) & \multicolumn{3}{|c|}{$\begin{array}{l}\text { uczestniczenie w spotkaniach społeczności przedsiębiorczych: konferencje, } \\
\text { spotkania, hackatony itp. }\end{array}$} \\
\hline
\end{tabular}

Źródło: Opracowanie własne.

Etap weryfikacji projektu stanowi główną treść zajęć, jest więc najobszerniejszy (ok. 60 proc. czasu przeznaczonego na zajęcia). Kluczowe elementy to oczywiście modelowanie biznesowe ( $w$ tym budowanie modeli przychodowych - "monetyzacja projektu"), przeprowadzenie wywiadów z potencjalnymi klientami i - ewentualnie - prototypowanie (w miarę możliwości). Chodzi tutaj zarówno o przekazanie niezbędnej wiedzy w tym zakresie, jak i o zrealizowanie praktycznych warsztatów na zajęciach oraz równoległą pracę studentów poza zajęciami (na przykład przeprowadzenie wywiadów).

Jednym z ważnych wyzwań na tym etapie zajęć z przedsiębiorczości innowacyjnej jest zastąpienie tradycyjnego narzędzia - biznesplanu - bardziej adekwatnym instrumentem, czyli modelowaniem biznesowym. W odniesieniu do przedsięwzięć innowacyjnych, zwłaszcza rozwijanych na 
rynkach, na których produkty lub usługi mają charakter niematerialny (na przykład wirtualny), biznesplan po prostu nie sprawdza się jako metoda organizacji pracy i zarządzania przedsięwzięciem (por. Blank 2013, Sommer, Loch, Dong 2009, Lange i in. 2007). Przedsiębiorca rozpoczyna działalność w warunkach tak wysokiej niepewności, że trafne przewidywanie zdarzeń i szacowanie głównych parametrów biznesu (przychodów, kosztów, wielkości sprzedaży i niezbędnych zasobów) przeważnie nie prowadzi do oczekiwanych rezultatów, czyli do obniżenia ryzyka przedsięwzięcia (por. Tanev 2017, Picken, 2017). Modelowanie biznesowe i-szerzej-metodyka zarządzania Lean Startup dostarczają tutaj lepszych od biznesplanu narzędzi rozwijania pomysłu w innowacyjny biznes (por. Skala 2018).

Ważnym elementem kształcenia w zakresie innowacyjnej przedsiębiorczości jest również zderzenie idei projektów rozwijanych przez studentów z realną opinią ich potencjalnych klientów, realizowana przez zaprojektowanie, przeprowadzenie i analizę wywiadów bezpośrednich, które potwierdzają główne hipotezy postawione na etapie modelowania biznesowego i (lub) pracy nad propozycją wartości, albo im zaprzeczają. Warto i na tym etapie podkreślać znaczenie myślenia efektuacyjnego (Sarasvathy 2008), które w budowaniu przedsięwzięć innowacyjnych sprawdza się lepiej niż myślenie przyczynowo-skutkowe. Na każdym etapie rozwoju projektu można ćwiczyć efektuacyjne sposoby myślenia, planując i realizując działania wyznaczane bardziej w funkcji dostępnych w danej chwili (zazwyczaj skromnych) zasobów niż dalekosiężnych, trudno osiągalnych celów.

Ostatni etap zajęć to przygotowanie do prezentacji końcowych rezultatów pracy studentów nad projektem (20 proc. dostępnego czasu). Doświadczenie wskazuje, że świadomość przybycia gości z praktyki biznesowej bardzo mobilizuje studentów na tym etapie. Warto zadbać, aby zasady przekazywania konstruktywnej krytyki projektów były jasno ustalone zarówno ze studentami, jak i z zaproszonymi gośćmi. Na uczelni wśród gości powinien się znaleźć ktoś z centrum transferu technologii lub z inkubatora przedsiębiorczości z realną ofertą wsparcia ze strony uczelni dla najlepszych zespołów.

\section{Kompetencje prowadzącego i osadzenie w ekosystemie przedsiębiorczości}

Kompetencje edukatora w zakresie innowacyjnej przedsiębiorczości są ważnym elementem procesu kształcenia. Sandra Waddock i Josep 
Lozano (2013) zwrócili uwagę na ten problem, stwierdzając, że potrzebne są badania nie tylko nad tym, jak najlepiej przygotować uczniów do przedsiębiorczej ścieżki rozwoju zawodowego, ale także nad właściwym wykształceniem kadr prowadzących zajęcia nowego typu. Wymagają one bowiem umiejętności, których nabycie jest czasochłonne i trudne do opanowania, zwłaszcza dla kadry uniwersyteckiej, która jest przeważnie bardziej skoncentrowana na działalności naukowej niż edukacyjnej, zwłaszcza zaś biznesowej. Sposobem na uzupełnienie tych braków jest właśnie wniknięcie w lokalny ekosystem przedsiębiorczości - zarówno prowadzących zajęcia, jak i słuchaczy. Ekosystemu nie tworzą sami przedsiębiorcy, lecz również inni ważni uczestnicy przedsiębiorczej społeczności: fundusze inwestycyjne, wyspecjalizowane instytucje państwowe, jednostki badawczo-rozwojowe, media branżowe, liderzy społeczności, korporacje, kancelarie prawne.

Prowadzący zajęcia powinien na tyle dobrze znać lokalny ekosystem przedsiębiorczości, aby zapewnić wizyty gości, zwłaszcza przedsiębiorców, a także zorganizować co najmniej jedną sesję mentoringową dla uczestników zajęć. Mentoring, jako najbardziej ceniony przez samych przedsiębiorców sposób pozyskiwania wiedzy i innych zasobów, na przykład cennych kontaktów biznesowych (Beauchamps, Krysztofiak-Szopa, Skala 2018, Beauchamps, Kowalczyk, Skala 2017), powinien być stałym elementem curriculum zajęć. W ten sposób uczestnicy mogą się przekonać o wartości mentoringu oraz nabyć zwyczaju korzystania z tej formy wsparcia.

Studenci powinni być także zobligowani do wzięcia udziału w kilku spotkaniach społeczności przedsiębiorców w czasie trwania semestru projektowego - poza uczelnią.

\section{Zakończenie}

Przedsiębiorczość innowacyjna stanowi tę część aktywności biznesowej, która wywiera spory w stosunku do swojej niewielkiej skali wpływ na rozwój ekonomiczno-społeczny. Wpływ ten przejawia się przez aplikację i komercjalizację postępu technicznego, generowanie nadwyżek finansowych i wpływów podatkowych oraz tworzenie nowych, trwałych i dobrych jakościowo miejsc pracy. Kształcenie na rzecz rozwoju przedsiębiorczości innowacyjnej jest krytycznie ważne dla właściwego funkcjonowania i pobudzania tej formy aktywności człowieka, przejawiającej się zarówno w zakładaniu nowych przedsięwzięć innowacyjnych (tak 
zwanych start-upów), jak i wykształcaniu proaktywnych i twórczych postaw wśród pracowników istniejących przedsiębiorstw.

Skuteczne kształcenie w tym zakresie wymaga z jednej strony nabycia specjalistycznej wiedzy i kompetencji przez edukatorów prowadzących tego typu zajęcia w ramach formalnego i pozaformalnego systemu edukacji, z drugiej zaś - wysokiego zaangażowania słuchaczy (uczniów, studentów, przedsiębiorców), świadomych znaczenia nabywanych kompetencji i umiejętności dla ich rozwoju zawodowego. Dążenie do bliższego powiązania systemu edukacji (na każdym jego poziomie) z rynkiem pracy i osiągnięcia strategicznego celu, jakim jest wyraźne podniesienie poziomu innowacyjności polskiej gospodarki, powinno jak najszybciej znaleźć odbicie w popularyzacji kształcenia na rzecz innowacyjnej przedsiębiorczości w polskich szkołach i na uniwersytetach. 


\section{Bibliografia}

$\rightarrow$ Andrews, D., Criscuolo C., Menon, C. (2014), Do resources ow to patenting firms? Cross-country evidence from firm level data, OECD Economic Department Working Papers, 1127.

$\rightarrow$ Baumol, W.J. (2010), The Microtheory of the Innovative Entrepreneur, Princeton, NJ, Oxford, UK: Princeton University Press.

$\rightarrow$ Beauchamp, M., Kowalczyk, A., Skala, A. (2017), Polskie Startupy. Raport 2017, Warszawa: Startup Poland.

$\rightarrow$ Beauchamp, M., Krysztofiak-Szopa, J., Skala, A. (2018), Polskie Startupy. Raport 2018, Warszawa: Startup Poland.

$\rightarrow$ Birch, D.L. (1979), The Job Generation Process, MIT program on neighborhood and regional change, Cambridge, $M A$.

$\rightarrow$ Birch, D.L. (1987), Job Creation in America: How Our Smallest Companies Put the Most People to Work, New York: The Free Press.

$\rightarrow$ Blanchenay, P.F., Calvino, C., Criscuolo, C., Menon, C. (2017), Cross-country Evidence on Business Dynamics over the Last Decade: From Boom to Gloom?, OECD Science, Technology and Industry, Working Paper.

$\rightarrow$ Blank, S. (2013), Why the lean start-up changes everything , "Harvard Business Review", 91 (5), s. 63-72.

$\rightarrow$ Block, J.H., Fisch, C.O., van Praag, M. (2017), The Schumpeterian entrepreneur: a review of the empirical evidence on the antecedents, behavior and consequences of innovative entrepreneurship, „Industry and Innovation", 24 (1), s. 61-95.

$\rightarrow$ Calvino, F.C., Criscuolo, C., Menon, C. (2016), No Country for Young Firms? Start-up Dynamics and National Policies, „OECD Science, Technology and Industry Policy Papers", 29, Paris: OECD Publishing.

$\rightarrow$ Cieślik, J. (2014), Przedsiębiorczość, polityka, rozwój, Warszawa: Wydawnictwo Akademickie Sedno. 
$\rightarrow$ Coad, A., Daunfeldt, S.O., Hölzl, W., Johansson, D., Nightingale, P. (2014), High-growth firms: introduction to the special section, "Industrial and Corporate Change", 23 (1), s. 91-112.

$\rightarrow$ Criscuolo, C., Gal, P.N., Menon, C. (2014), The Dynamics of Employment Growth: New Evidence from 18 Countries, „OECD Science, Technology and Industry Policy Papers", 14, Paris: OECD Publishing.

$\rightarrow$ Decker, R.A., Haltiwanger, J., Jarmin, R.S., Miranda, J. (2016), Where has all the skewness gone? The decline in high-growth (young) firms in the US, „European Economic Review", 86, s. 4-23.

$\rightarrow$ Drucker, P.F. (1992), The new society of organizations, „Harvard Business Review".

$\rightarrow$ Fairlie, R.W., Kapur, K., Gates, S. (2011), Is Employer-based Health Insurance a Barrier to Entrepreneurship?, "Journal of Health Economics”, 30 (1), s. 146-162 .

$\rightarrow$ Fayolle, A., Lassas-Clerc, N. (2006), Essay on the nature of entrepreneurship education, International Conference Entrepreneurship in United Europe-Challenges and Opportunities.

$\rightarrow$ Guzman, J., Stern, S. (2016), The State of American Entrepreneurship: New Estimates of the Quantityand Quality of Entrepreneurship for 15 US States, 1988-2014, National Bureau of Economic Research, Working Paper, 22095.

$\rightarrow$ Haltiwanger, J., Jarmin, R.S., Miranda, J. (2013), Who creates jobs? Small versus large versus young, „Review of Economics and Statistics", 95 (2), s. 347-361.

$\rightarrow$ Henry, C., Hill, F., Leitch, C. (2005a), Entrepreneurship education and training: can entrepreneurship be taught?, cz. 1, „Education + Training”, 47 (2), s. 98-111.

$\rightarrow$ Henry, C., Hill, F., Leitch, C. (2005b), Entrepreneurship education and training: can entrepreneurship be taught?, cz. 2, „Education + Training”, 47 (3), s. 158169.

$\rightarrow$ Kirby, D.A. (2004), Entrepreneurship education: can business schools meet the challenge?, "Education + Training”, 46 (8/9), s. 510-519.

$\rightarrow$ Koźmiński, A.K. (2011), The new revolution in management education?, „Master of Business Administration", 19 (4), s. 2-6.

$\rightarrow$ Kösters, S. (2010), Subsidizing Start-ups: Policy Targeting and Policy Effectiveness, "Journal of Industry, Competition and Trade”, 10 (3-4), s. 199-225.

$\rightarrow$ Kuckertz, A. (2013), What's Hot in Entrepreneurship Research in 2013?, The 1st of a Series of Annual Trend Surveys, Hohenheim: Universität Hohenheim.

$\rightarrow$ Kuckertz, A., Prochotta, A. (2018), What's Hot in Entrepreneurship Research in 2018?, Hohenheim Entrepreneurship Research Brief, Hohenheim: Universität Hohenheim. 
$\rightarrow$ Kuratko, D.F. (2005), The emergence of entrepreneurship education: Development, trends, and challenges, „Entrepreneurship Theory and Practice”, 29 (5), s. 577-598.

$\rightarrow$ Lange, J.E., Mollov, A., Pearlmutter, M., Singh, S., Bygrave, W.D. (2007), Pre-start-up formal business plans and post-start-up performance: A study of 116 new ventures, „Venture Capital”, 9 (4), s. 237-256.

$\rightarrow$ Matlay, H. (2005), Entrepreneurship education in UK business schools: Conceptual, contextual and policy considerations, „Journal of Small Business and Enterprise Development", 12 (4), s. 627-643.

$\rightarrow$ McKeown, J., Millman, C., Reddy Sursani, S., Smith, K., Martin, L.M. (2006), Graduate entrepreneurship education in the United Kingdom, "Education + Training", 48 (8/9), s. 597-613.

$\rightarrow$ McMullan, W.E., Long, W.A. (1987), Entrepreneurship education in the nineties, "Journal of Business Venturing", 2 (3), s. 261-275.

$\rightarrow$ Mwasalwiba, E.S. (2010), Entrepreneurship education: a review of its objectives, teaching methods, and impact indicators, "Education + Training", 52 (1), s. 20-47.

$\rightarrow$ Picken, J.C. (2017), From startup to scalable enterprise: Laying the foundation, „Business Horizons", 60 (5), s. 587-595.

$\rightarrow$ Pittaway, L., Cope, J. (2007), Entrepreneurship education: a systematic review of the evidence, "International Small Business Journal”, 25 (5), s. 479-510.

$\rightarrow$ Rannikko, H., Autio, E. (2016), Retaining Winners: Can Policy Boost High-growth Entrepreneurship?, „Research Policy”, 45 (1), s. 42-55.

$\rightarrow$ Sarasvathy, S. (2008), Effectuation: elements of entrepreneurial expertise, Northampton: Edward Elgar Publishing.

$\rightarrow$ Schoar, A. (2010), The divide between subsistence and transformational entrepreneurship, "Innovation Policy and the Economy, 10 (1), s. 57-81.

$\rightarrow$ Schumpeter, J. (1942), Capitalism, Socialism and Democracy, New York: Harper $\&$ Brothers.

$\rightarrow$ Shane, S.A. (2008), The Illusions of Entrepreneurship: The Costly Myths that Entrepreneurs, Investors and Policy Makers Live By, New Haven: Yale University Press.

$\rightarrow$ Skala, A. (2016), Badanie efektywności programów edukacyjnych w zakresie przedsiębiorczości na podstawie studium przypadku Politechniki Warszawskiej - komunikat z badań, „Przedsiębiorczość - Edukacja”, 12, s. 364-377.

$\rightarrow$ Skala, A. (2018), Startupy. Wyzwanie dla zarządzania i edukacji przedsiębiorczości, Kraków: edu-Libri. 
$\rightarrow$ Sommer, S.C., Loch, C.H., Dong, J. (2009), Managing complexity and unforeseeable uncertainty in startup companies: An empirical study, "Organization Science", 20 (1), s. 118-133.

$\rightarrow$ Stępniak-Kucharska, A. (2015), Rola państwa we wspieraniu działalności badawczo-rozwojowej polskich przedsiębiorstw, "Studia Ekonomiczne”, 209, s. 199-208.

$\rightarrow$ Tanev, S. (2017), Is There a Lean Future for Global Startups?, „Technology Innovation Management Review", 7 (5), s. 6-15.

$\rightarrow$ Vanevenhoven, J. (2013), Advances and challenges in entrepreneurship education, „Journal of Small Business Management”, 51 (3), s. 466-470.

$\rightarrow$ Vesper, K.H., Gartner, W.B. (1997), Measuring progress in entrepreneurship education, "Journal of Business Venturing", 12 (5), s. 403-421.

$\rightarrow$ Wach, K. (2013), Edukacja na rzecz przedsiębiorczości wobec współczesnych wyzwań cywilizacyjno-gospodarczych, „Przedsiębiorczość - Edukacja”, 9, s. 246-257.

$\rightarrow$ Waddock, S., Lozano, J.M. (2013), Developing more holistic management education: Lessons learned from two programs, „Academy of Management Learning \& Education", 12 (2), s. 265-284.

$\rightarrow$ Wong, P., Ho, Y., Autio, E. (2005), Entrepreneurship, innovation and economic growth: Evidence from GEM data, "Small Business Economics”, 24 (3), s. 335-350. 


\section{Netografia}

$\rightarrow$ Charney, A., Libecap, G.D. (2000), The Impact of Entrepreneurship Education: An Evaluation of the Berger Entrepreneurship Program at the University of Arizona, 1985-1999, Final Report, ebr.eller.arizona.edu/sites/ebr/les/docs/research-studies/impact-of-entrepreneurship-education-1985-1999.pdf (dostęp: 9.05.2018).

$\rightarrow$ Cieślik, J. (2018), Samozatrudnieni jako adresaci polityki wspierania przedsiębiorczości i systemu ubezpieczeń społecznych, Alert Centrum Przedsiębiorczości ALK, 11/3, www.cieslik.edu.pl/wp-content/uploads/2018/09/ Alert_11_03.2018_CP_ALK-Samozatrudnieni-jako-adresaci-polityki-wspierania-przedsiębiorczości.pdf (dostęp: 10.11.2018).

$\rightarrow$ Kurczewska, A. (2012), W jaki sposób myślq przedsiębiorcy? - czyli: „jeśli mogę kontrolować przyszłość, nie muszę jej przewidywać", „e-mentor", 5 (47), www.e-mentor.edu.pl/artykul/index/numer/47/id/965 (dostęp: 30.10.2017).

$\rightarrow \quad \mathrm{Ng}$, W., Stuart, T.E. (2016), Of Hobos and Highfliers: Disentangling the Classes and Careers of Technology-Based Entrepreneurs, Working Paper, www.gsb. stanford.edu/sites/gsb/ les/ng_italk2016_0.pdf (dostęp: 20.02.2017).

$\rightarrow$ Rozporządzenie Ministra Edukacji Narodowej z dnia 30 stycznia 2018 r.oku w sprawie podstawy programowej kształcenia ogólnego dla liceum ogólnokształcącego, technikum oraz branżowej szkoły Il stopnia (Dz.U. 2018, poz. 467), prawo.sejm.gov.pl/isap.nsf/DocDetails.xsp?id=WDU20180000467 (dostęp 29.11.2018). 